\title{
Respiratory Tract Bacterial Colonization in Long-Term Tracheostomized Pediatric Patients: Comparison between Sites and Two Different Timepoints
}

\author{
Seung Hoon $\operatorname{Han}^{1}$ (D), Young Seok Kim ${ }^{1}$ (D), and Seong Keun Kwon ${ }^{1,2}$ (1) \\ 'Department of Otorhinolaryngology-Head and Neck Surgery, Seoul National University Hospital, Seoul, Korea \\ 2Department of Otorhinolaryngology-Head and Neck Surgery, Seoul National University College of Medicine, Seoul, Korea
}

\section{장기간 기관절개공을 유지한 소아 환자들에서의 기도 세균집락에 관한 연구: \\ 균동정 부위와 시차 간의 차이 비교}

한승훈 ${ }^{1}$, 김영석 ${ }^{1}$, 권성근 1,2

서울대학교병원 이비인후과, ${ }^{1}$ 서울대학교 의과대학 이비인후과학교실 2

\begin{abstract}
Background and Objectives Tracheostomy lead to persistent bacterial colonization of the respiratory tract. Surgical site infection and restenosis by the pathogenic bacteria is the most fatal complication after open airway surgery. The aim of this study is to describe the culture results of larynx and tracheostoma in patients with tracheostomy and the preoperative, intraoperative culture results in patients underwent open airway surgery.

Materials and Method A retrospective review was performed on 18 patients who underwent culture between 2017 and 2019.

Results Pseudomonas or antibiotic resistance bacteria were identified in 11 patients out of 18 patients (61.1\%); Ceftriaxone-resistant Streptococcus (38.9\%), Pseudomonas (33.3\%), Methicillin-resistant Staphylococcus aureus (16.7\%), extended-spectrum $\beta$-lactamases (ESBL) producing Klebsiella pneumoniae (11.1\%). Among 18 patients, 6 patients showed the different culture result between larynx and tracheostoma. In 4 out of 10 patients who underwent open airway surgery, the bacteria were not identified before surgery, but the bacteria were isolated in the intraoperative culture. In one patient, the bacteria detected intraoperatively were different from those detected before surgery.

Conclusion Preoperative respiratory tract culture and usage of perioperative antibiotics according to the culture are necessary. It is crucial to verify the bacterial culture in both tracheostoma and larynx. And it should be performed immediately before open airway surgery.
\end{abstract}

Keywords Subglottic stenosis; Tracheostomy; Bacterial culture test; Antimicrobial susceptibility test; Prophylactic antibiotics.

\section{서 론}

내시경적 치료가 실패하거나 중등도 이상의 후두 기관협착에서 기도 재건을 위한 개방
Received December 15, 2020

Revised January 13, 2021

Accepted January 28, 2021

\section{Corresponding Author}

Seong Keun Kwon, MD, PhD

Department of Otorhinolaryngology-

Head and Neck Surgery,

Seoul National University

College of Medicine,

101 Daehak-ro, Jongno-gu,

Seoul 03080, Korea

Tel +82-2-2072-2286

Fax+82-2-745-2387

E-mail otolarynx@snuh.org

\section{ORCID iDs}

Seung Hoon Han (D)

https://orcid.org/0000-0001-7156-993X

Young Seok Kim (D)

https://orcid.org/0000-0002-5042-6048

Seong Keun Kwon (D)

https://orcid.org/0000-0001-9218-7666

This is an Open Access article distributed under the terms of the Creative

Commons Attribution Non-Commercial License (https://creativecommons.org/ licenses/by-nc/4.0) which permits unrestricted non-commercial use, distribution, and reproduction in any medium, provided the original work is properly cited. 
적 기도재건술을 하게 된다. 일반적으로 수술적 대상이 되는 환아들은 대부분 이전에 기관절개술을 시행하였으며 기관절 개공을 장기간 유지하는 경우가 많다. 기관절개술 이후에는 균이 점액섬모청소기전(mucociliary clearance mechanism) 을 포함한 상기도의 방어체계를 우회하며 기관절개관 자체 가 균 집락화의 병소가 된다는 점에서 감염에 취약해진다[1]. 이러한 점은 개방적 기도수술 이후 병원균에 의해 수술 부위 감염과 재협착 등의 치명적인 합병증을 일으키게 되는 원인 이 된다[2,3]. 치명적인 합병증을 피하기 위해서는 수술 전후 적절한 항생제 사용이 필요하며 항생제 선택을 위해서 상재 하는 균에 대한 동정이 필요하다. 그러나 현재 장기간 기관절 개관을 가지고 있는 환아들의 기도에 상재하는 균에 대한 연 구가 드물고, 특히 국내에서 시행된 연구는 거의 없으며 개방 적 기도재건술에서 사용하는 예방적 항생제의 대상이 되는 균 에 대한 자료가 없다. 그러므로 본 연구를 통하여 첫 번째로 장기간 기관절개공을 유지한 환아들에서 동정 위치에 따른 집락 미생물군과 항생제 내성균에 대해 살펴보고자 한다. 그 리고 두 번째로 개방적 기도재건술을 시행한 환아에서 후두 와 기관절개공에서 시행한 균 동정 결과에 차이가 있는지, 또 한 균 동정 시점에 따라 변화가 있는지 확인하고자 한다.

\section{대상 및 방법}

대 상

본 연구는 서울대학교병원 기관윤리심의위원회의 승인을
받았으며(승인 번호: 1907-152-1050), 2017년 3월 2019년 7월 까지 단일 기관에서 기관절개공과 후두에서 각각 균 동정을 시행한 18세 미만 소아 환자를 대상으로 후향적으로 분석하 였다. 개방적 기도수술을 준비하는 과정에서 수술실에서 전신 마취하에 현수후두경검사를 시행하며 기관절개공과 후두, 두 군데 모두에서 멸균면봉균배양을 시행하였다(Fig. 1). 검사 당 시 기관절개공에 화농성 분비물이 있거나 감염 징후를 보였 던 환아는 제외하였다. 상기 조건에 포함되는 분석에 이용된 환자는 총 18 명이었으며 이 중 10 명의 환자가 연구 기간 중에 개방적 기도수술을 시행받았다.

\section{방 법}

대상 환자의 의무기록을 바탕으로 균 동정 결과, 기관절개 술 시행 당시의 나이, 기관절개공 유지 기간을 후향적으로 조 사하였다. 또한 개방적 기도수술을 받은 10 명의 환자들에 대 하여 수술 전과 수술 중에 시행한 균 동정 결과, 수술 부위 감 염 여부와 재원 기간을 분석하였다.

\section{통계 분석}

두 군 간 연속형 변수에 대해 Mann-Whiteny 검정을 통하 여 비교하였다. 범주형 변수에 대해서는 카이 제곱 검정 및 Fisher의 정확 검정을 사용하여 비교하였다. 통계 분석은 SPSS for Windows ver. 20.0(IBM Corp., Armonk, NY, USA)을 이용하였고 $\mathrm{p}$-value $<0.05$ 를 통계적으로 유의한 것 으로 간주하였다.
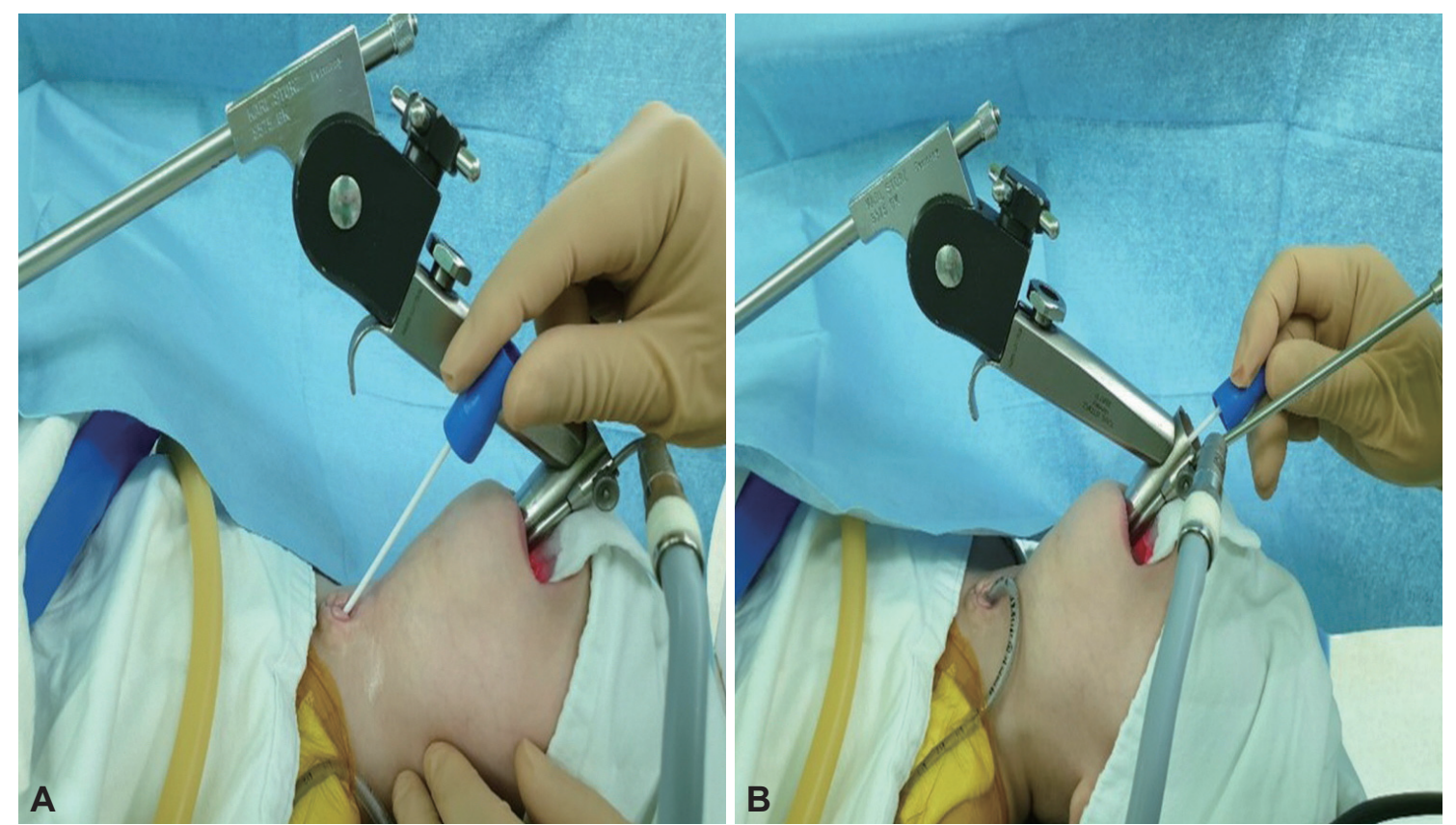

Fig. 1. Representative photos of bacterial swab culture procedure in pediatric patient with tracheostomy. A: Tracheostomal swab culture. B: Laryngeal swab culture. 


\section{결 과}

\section{균 동정 결과}

균 동정 당시 나이는 평균 52.9 개월, 기관절개술은 평균 생 후 4.9개월에 받았던 환자들로 평균 47.7개월 동안 기관절개 관을 가지고 있었다. 이 중 개방적 기도수술은 10 명의 환아에 서 시행되었다(Table 1).

균 동정 결과 총 71예의 균이 동정되었으며 기관절개공에서는 35 예, 후두에서는 36예의 다양한 균들이 동정되었다(Table 2). 기관절개공, 후두에서 ceftriaxone 민감성 사슬알균(Streptococcus)이 각각 9예로 가장 많이 동정되었다. 임상적으로 흔 한 감염원인 녹농균(Pseudomonas)과 잠재적 병원균으로서 항생제 선택에 주의를 요하는 항생제 내성균은 기관절개공에 서 총 14 예, 후두에서 13 예 동정되었다. 그 중 기관절개공에서 는 녹농균이 6예로 가장 많이 동정되었다. 반면에 후두에서 는 ceftriaxone 내성 사슬알균이 6예로 가장 흔했고 녹농균은 3 예 동정되었다. 18 명의 환자 중에 11 명에서 균이 동정되었으 며 균 동정 검사 시행 위치로 보면 기관절개공과 후두에서 동 일한 결과를 냈던 환자가 5 명이었으며 차이가 있었던 환자는 6명이었다(Table 3). 차이가 있었던 6명 중 2명에서 후두에서 동정된 균에 추가하여 기관절개공에서 각각 녹농균, ceftri- axone 내성 사슬알균이 동정되었다. 다른 2명에서 기관절개공 에서는 녹농균, 후두에서는 ceftriaxone 내성 사슬알균이 각 각 동정되었다. 또한 1 명은 후두에서는 동정되지 않았지만 기 관절개공에서 methicillin 내성 황색포도알균(Staphylococcus aureus)이 동정되었다. 나머지 1명에서는 반대로 기관절개공에 서 동정되지 않았던 methicillin 내성 황색포도알균, 녹농균이 후두에서 동정되었다. 녹농균 또는 항생제 내성균이 동정된 환자군과 동정되지 않은 환자군을 나누어 성별, 나이, 기관절 개술 시행 당시 나이와 기간을 비교하였을 때 두 군 간의 유 의한 차이를 보이지 않았다(Table 1). 기관절개공과 후두 사 이에 동정 균의 차이가 있는 군과 없는 군 간의 균 동정 당시 나이 $(\mathrm{p}=0.825)$, 기관절개술 시행 당시 나이 $(\mathrm{p}=0.257)$, 기관절 개공 유지 기간 $(\mathrm{p}=0.868)$ 은 유의한 차이를 보이지 않았다.

\section{개방적 기도수술 시행군에서 동정된 병인균 분석} 개방적 기도수술이 시행된 10 명을 살펴보면 수술 전 녹농 균 또는 항생제 내성균이 동정되지 않은 4명에서도 수술 중 시행한 균 동정에서는 동정되었다(Table 4). 9 명에서 기관절개 공과 후두에서 같은 균이 확인되었으며 1 명의 환자에서 기관 절개공에서는 검출되지 않았으나 후두에서 methicillin 내성 황색포도알균이 검출되었다. 수술 직전 균 동정을 다시 시행

Table1. Comparison of clinical features according to isolated microorganisms

\begin{tabular}{lcccc}
\multicolumn{1}{c}{ Variables } & Value $(\mathrm{n}=18)$ & $\begin{array}{c}\text { Pseudomonas or antibiotic } \\
\text { resistance bacteria }(\mathrm{n}=11)\end{array}$ & $\begin{array}{c}\text { Other bacteria }(\mathrm{n}=7) \\
\mathrm{p} \text { value }\end{array}$ \\
Age (month) & $52.9 \pm 26.6$ & $44.1 \pm 13.3$ & $65.2 \pm 36.8$ & 0.161 \\
Male & $9(50.0)$ & $5(45.5)$ & $4(57.1)$ & 0.629 \\
Age of tracheostomy (month) & $4.9 \pm 5.7$ & $6.2 \pm 6.9$ & $3.5 \pm 2.0$ & 0.256 \\
T-cannula period (month) & $47.7 \pm 26.7$ & $37.8 \pm 12.3$ & $61.0 \pm 36.2$ & 0.118 \\
Airway reconstruction surgery & $10(55.6)$ & $6(54.5)$ & $4(57.1)$ & 0.914 \\
\hline
\end{tabular}

Data are presented as $\mathrm{n}(\%)$ or mean \pm standard deviation

Table 2. Details of isolated microorganisms

\begin{tabular}{lccc} 
& Tracheostoma $(\mathbf{n}=35)$ & Larynx $(\mathbf{n}=36)$ & Total $(\mathbf{n}=71)$ \\
Pseudomonas or antibiotic resistance bacteria & & & $4(5.63)$ \\
Methicillin resistance Staphylococcus & $2(5.71)$ & $2(5.56)$ & $9(12.7)$ \\
Pseudomonas & $6(17.1)$ & $3(8.3)$ & $10(14.1)$ \\
Ceftriaxone resistance Streptococcus & $4(11.4)$ & $6(16.7)$ & $4(5.63)$ \\
ESBL(+) Klebsiella & $2(5.71)$ & $2(5.56)$ & $6(8.45)$ \\
Other bacteria & & & $18(25.4)$ \\
Methicillin sensitive Staphylococcus & $3(8.57)$ & $3(8.33)$ & $2(2.82)$ \\
Ceftriaxone sensitive Streptococcus & $9(25.7)$ & $9(25.0)$ & $5(7.04)$ \\
ESBL(-) Klebsiella & $1(2.86)$ & $1(2.28)$ & $4(5.63)$ \\
Serratia & $3(8.57)$ & $2(5.56)$ & $9(12.7)$ \\
Rothia & $1(2.86)$ & $3(8.33)$ & $5(13.9)$ \\
Others & $4(11.4)$ & & \\
\hline
\end{tabular}

Data are presented as n (\%). ESBL: extended spectrum $\beta$-lactamases 
Table 3. Details of isolated Pseudomonas or antibiotic resistance bacteria

\begin{tabular}{|c|c|c|c|c|c|c|c|}
\hline Case & Sex & $\begin{array}{l}\text { Age at tracheostomy } \\
\text { (month) }\end{array}$ & $\begin{array}{l}\text { Age at culture } \\
\text { (month) }\end{array}$ & $\begin{array}{c}\text { T-cannula } \\
\text { period (month) }\end{array}$ & Tracheostoma & Larynx & Comorbidities \\
\hline 1 & $\mathrm{~F}$ & 5 & 46 & 41 & P, CRS & CRS & $(-)$ \\
\hline 2 & M & 6 & 132 & 125 & CRS, ESBLK & ESBLK & Prematurity \\
\hline 3 & $\mathrm{~F}$ & 7 & 25 & 24 & MRSA & $(-)$ & $(-)$ \\
\hline 4 & M & 4 & 35 & 31 & $\mathrm{P}$ & CRS & Neuromuscular disease \\
\hline 5 & $\mathrm{~F}$ & 7 & 63 & 56 & $\mathrm{P}$ & CRS & Neuromuscular disease \\
\hline 6 & M & 5 & 58 & 53 & $(-)$ & MRSA, CRS & RDS \\
\hline 7 & $\mathrm{~F}$ & 5 & 27 & 22 & CRS & CRS & RDS \\
\hline 8 & M & 5 & 37 & 32 & $\mathrm{P}$ & $\mathrm{P}$ & BPD \\
\hline 9 & $\mathrm{~F}$ & 2 & 36 & 34 & $\mathrm{P}$ & $\mathrm{P}$ & BPD \\
\hline 10 & $\mathrm{~F}$ & 1 & 45 & 44 & MRSA, P & MRSA, P & Heart disease \\
\hline 11 & M & 7 & 61 & 53 & CRS, ESBLK & CRS, ESBLK & Prematurity \\
\hline 12 & $\mathrm{~F}$ & 6 & 132 & 125 & $(-)$ & $(-)$ & RDS \\
\hline 13 & M & 5 & 37 & 31 & $(-)$ & $(-)$ & RDS \\
\hline 14 & $\mathrm{~F}$ & 3 & 32 & 29 & $(-)$ & $(-)$ & Heart disease \\
\hline 15 & M & 3 & 36 & 33 & $(-)$ & $(-)$ & Heart disease \\
\hline 16 & M & 2 & 61 & 58 & $(-)$ & $(-)$ & Heart disease \\
\hline 17 & M & 2 & 93 & 90 & $(-)$ & $(-)$ & RDS \\
\hline 18 & $\mathrm{~F}$ & 0 & 76 & 76 & $(-)$ & $(-)$ & $(-)$ \\
\hline
\end{tabular}

MRSA: methicillin-resistance Staphylococcus aureus, ESBLK: extended spectrum $\beta$-lactamases (+) Klebsiella, CRS: ceftriaxone resistance Streptococcus, P: Pseudomonas, RDS: respiratory distress syndrome, BPD: bronchopulmonary dysplasia

Table 4. Clinical features in patient with open airway surgery

\begin{tabular}{|c|c|c|c|c|c|}
\hline Case & Preoperative culture & Operation & $\begin{array}{l}\text { Interval between culture } \\
\text { and operation (day) }\end{array}$ & Intraoperative culture & Hostpital days \\
\hline \multirow[t]{2}{*}{1} & 1st (-) & LTR ACCG & 1st 336 & MRSA & 9 \\
\hline & 2nd MRSA & & 2nd 119 & & \\
\hline 2 & $(-)$ & LTR ACCG & 49 & CRS & 8 \\
\hline 3 & $(-)$ & pCTR & 79 & CRS & 24 \\
\hline 4 & $(-)$ & LTR PCCG & 42 & CRS & 10 \\
\hline \multirow[t]{2}{*}{5} & 1st P, CRS & LTR ACCG & 1st 119 & $(-)$ & 10 \\
\hline & 2nd (-) & & 2nd 34 & & \\
\hline 6 & $\mathrm{P}$ & $\mathrm{pCTR}$ & 84 & $\mathrm{P}$ & 30 \\
\hline 7 & MRSA & pCTR & 57 & MRSA & 25 \\
\hline \multirow[t]{2}{*}{8} & 1st MRSA, P & pCTR & 1st 136 & MRSA & 15 \\
\hline & 2nd MRSA & & 2nd 63 & & \\
\hline 9 & P, CRS & LTR ACCG & 48 & MRSA & 36 \\
\hline 10 & $\mathrm{P}$ & LTR PCCG & 94 & $\mathrm{P}$ & 13 \\
\hline
\end{tabular}

MRSA: methicillin-resistance Staphylococcus aureus, CRS: ceftriaxone resistance Streptococcus, P: Pseudomonas, LTR: laryngotracheal reconstruction, ACCG: anterior costal cartilage graft, pCTR: partial cricotracheal resection, PCCG: posterior costal cartilage graft

했던 환자는 총 3 명이었으며 특히 1 번 환자에서는 최초의 균 동정에서 동정되지 않은 methicillin 내성 황색포도알균이 수 술 직전과 수술 중 검사에서 동정되었다. 수술 후 감염 징후를 보였던 9번 환자는 수술 전 동정되지 않았던 methicillin 내성 황색포도알균이 수술 중 시행한 검사에서 동정되었다. 수술 후 재원 기간은 수술 전 병인균 유무와 유의한 관계를 보이지 는 않았다 $(\mathrm{p}=0.189)$.

\section{고 찰}

본 연구의 목적은 개방적 기도수술을 시행하기 전 효과적 인 예방적 항생제를 선택하기 위해서 장기간 기관절개공을 유지하고 있는 환아들을 대상으로 세균집락을 알아보고자 하였다. 소아에서 후두 기관협착은 여러 원인과 복합적인 기 전에 의해 발생하며 호흡, 발성 등에 영향을 준다. 환자마다 원 
인, 부위, 협착 정도가 다르므로 이에 따른 적절한 수술 방법 선택이 중요하며, 수술 이후에 지속적인 처치와 경과 관찰이 필요하다[4]. 개방적 수술은 내시경적 치료가 실패한 경우나 중 등도 이상 협착에서 주로 이루어진다. 수술적 치료 시행 전에 성대마비 여부를 확인해야 하며 기도를 확보한 이후에도 기 관절개를 유지해야 하는 만성폐질환이나 신경학적 손상이 있 는지도 확인해야 한다.

개방적 수술 이후 발생한 감염은 수술 부위 회복을 방해하 고 수술 실패의 원인이다. 따라서 성공적인 수술을 위해서는 감염을 예방하고, 적절히 대처하는 것이 중요하다. 수술 전후 기의 예방적인 항생제의 사용은 수술 후 감염의 위험성을 감 소시킬 수 있는 것으로 확인되어 적절한 예방적 항생제를 선 택하여 사용하는 것이 중요하다[3].

개방적 기도수술은 수술 부위 특성상 기관 내 분비물에 의 한 경부 조직 오염을 피할 수 없다는 점에서 감염의 가능성이 높다. 이는 상처 감염을 일으키고 늑연골 이식 실패 등의 치명 적인 결과를 낳을 수 있다. 또한 수술 중에 출혈로 인해 혈액 이 열린 기관을 따라 흡인되고, 늑연골 채취로 인하여 흥부 통 증이 정상적인 기침을 방해한다는 점도 다른 수술과 비교하 여 개방적 기도수술이 감염에 취약한 원인이다. 그리고 기도 수술 이후 일정 기간 동안 중환자실에서 기계호흡기를 통해 호 흡하게 된다는 점에서 무기폐, 폐렴 등의 가능성도 증가한다.

개방적 기도수술에서 감염의 원인이 되는 균은 대부분 기 관절개공을 통해서 감염된다[3]. 기관절개공은 구강분비물과 감염된 가래에 노출되어 있고 피부에 세균총이 집락하는 피 부와 접해 있다는 점에서 감염에 취약한 것으로 알려져 있다 [5-8]. 이러한 감염은 국소조직 염증부터 종격동염, 괴사성 근 막염까지 일으킬 수 있다[5-7]. 기관절개술에 창상 감염을 일 으키는 원인균으로는 녹농균, 황색포도알균, 사슬알균이 알 려져 있다[5,9-11]. 또한 기관절개술을 시행받고 기관절개관 을 장기간 유지하는 경우에 기관절개관에 균막(biofilm)이 형성되어 균 집락화가 일어나기 쉽다[1]. 주로 녹농균이나 황 색포도알균의 집락화가 많이 일어난다[1,12-14]. 본 연구에서 도 기관절개공에서 시행한 균 동정에서 병인균으로 녹농균이 가장 많이 동정되었고 이를 예방적 항생제 선택에 고려해야 할 부분으로 사료된다.

Polubothu 등[9]은 표준적으로 소아 개방적기도수술에 $\mathrm{CO}^{-}$ amoxiclav를 7일 사용하며, methicillin 내성 황색포도알균 등 과 같은 항생제 내성균이 집락한 경우에는 vancomycin, 그 리고 기관절개공을 가진 환아에서는 녹농균의 집락이 많이 이루어진다는 점에서 녹농균 항균약제를 사용한다고 하였다. 이는 예방적 항생제를 사용하지 않은 군과 비교해서 수술 부 위 감염과 흥부 감염을 낮출 수 있었다고 한다[7]. 또한 Sitti- trai와 Siriwittayakorn[15]은 비록 소아의 개방적 기도수술 은 아니지만 수술 부위의 유사성을 고려했을 때 기관절개술에 서 적합한 예방적 항생제에 대한 연구에서 그람양성균과 음 성균을 항균 범위에 포함하는 clindamycin과 3세대 cephalosporin을 같이 사용하는 것을 제안하였다.

본 연구에서는 장기간 기관절개공을 가지고 있는 환아들에 게서 균 동정을 시행한 결과 감염 소견이 없음에도 $61.1 \%$ 환 자들에서 녹농균이나 항생제 내성균이 동정되었다. 이는 개방 적 기도수술 전 균 동정을 시행하고 이에 따라 수술 전후 효 과적인 항생제를 사용하는 것이 필요하다는 점을 말해준다. 동일 환자에서 최초의 균 동정에서 동정되지 않았던 methicillin 내성 황색포도알균이 수술 직전과 수술 중 검사에서 동정되었다는 점을 미루어봤을 때 항생제 결정을 위한 균 동 정은 가급적 수술 직전에 시행하는 것이 바람직하다. 또한 수 술 전에 동정된 균과 수술 후의 균이 다른 경우도 있으므로 반드시 수술 중에 균 동정을 하고 항생제 변경이 필요할 수도 있다. $16.7 \%$ 환자에서는 기관절개공에서 동정되지 않은 항생 제 내성균이 후두에서 동정되었다. 이는 수술 전 항생제 사용 을 위한 균 동정을 시행할 때 기관절개공에서만 시행하지 말 고 후두 부위에서도 균 동정 시행이 필요할 수 있음을 보여 준다.

이번 연구에서 동정 부위에 따라 동정된 균이 같은 군과 다 른 군 간에 개방적 기도수술 시행 시 나이, 기관절개술 시행 나이, 기관절개관 유지 기간 등의 유의한 차이는 없었다. 마찬 가지로 녹농균이나 항생제 내성균이 동정되었던 군과 동정되 지 않았던 군 사이에도 각 요인에 대해 유의한 차이가 없었다. 이는 연구 대상 수가 작은 것이 원인일 수 있고 실제로 이러한 요인들이 연관이 없을 수도 있다. 이를 확인하기 위해서는 다 른 요인들을 포함하여 다수를 대상으로 추가 연구가 필요하 다. 그리고 본 연구에서는 항생제 내성에 영향을 미칠 수 있 는 기저질환의 중증도와 항생제 사용 병력을 고려하지 않았 기 때문에 향후 연구에서 이 부분에 대한 보완이 필요하다.

\section{결 론}

기관절개공을 가진 환아에서 주로 녹농균 또는 항생제 내 성균을 확인하였다. 개방적 기도수술에서 감염은 치명적이므 로 수술 전 균 동정 결과에 따라 적절한 항생제를 예방적으로 사용하는 것이 중요하다. 그러나 기관절개공과 후두 사이에 도 동정 결과가 다를 수 있으므로 두 부위 모두 균 동정을 시 행하여 확인하는 것이 필요하다. 또한 수술 전과 수술 중 시행 한 동정에도 차이가 있을 수 있으므로 수술 중 동정이 반드시 필요하며 이에 따라 적절한 항생제 변경도 고려해야 한다. 
중심 단어: 성문하협착, 기관절개술, 균 배양검사, 항생제 감수 성, 예방적 항생제.

\section{Acknowledgments}

This work was supported by the National Research Foundation of Korea (NRF) grant funded by the Korea government (MSIT) (2020R1A4A4079931).

Conflicts of Interest

The authors have no financial conflicts of interest.

\section{Authors' Contribution}

Conceptualization: all authors. Data curation: Seung Hoon Han, Young Seok Kim. Investigation: all authors. Methodology: all authors. Writing-original draft: Seung Hoon Han. Writing-review \& editing: Young Seok Kim, Seong Keun Kwon. Approval of final manuscript: all authors.

\section{REFERENCES}

1. Sanders CD, Guimbellot JS, Muhlebach MS, Lin FC, Gilligan P, Esther CR Jr. Tracheostomy in children: epidemiology and clinical outcomes. Pediatr Pulmonol 2018;53(9):1269-75.

2. Madariaga ML, Gaissert HA. Reresection for recurrent stenosis after primary tracheal repair. J Thorac Dis 2016;8(Suppl 2):S153-9.

3. Prescott CA. Factors that influence successful decannulation after surgery for laryngo-tracheal stenosis in children. Int J Pediatr Otorhinolaryngol 1994;30(3):183-8.

4. Ryu IS, Choi SH. Laryngotracheal stenosis. J Korean Soc Laryngol Phoniatr Logop 2012;23(1):21-7.

5. Goldenberg D, Ari EG, Golz A, Danino J, Netzer A, Joachims HZ. Tracheotomy complications: a retrospective study of 1130 cases. Otolaryngol Head Neck Surg 2000;123(4):495-500.
6. Wang RC, Perlman PW, Parnes SM. Near-fatal complications of tracheotomy infections and their prevention. Head Neck 1989;11(6): 528-33.

7. Cipriano A, Mao ML, Hon HH, Vazquez D, Stawicki SP, Sharpe RP, et al. An overview of complications associated with open and percutaneous tracheostomy procedures. Int J Crit Illn Inj Sci 2015;5(3):17988 .

8. Briggs S, Ambler J, Smith D. A survey of tracheostomy practice in a cardiothoracic intensive care unit. J Cardiothorac Vasc Anesth 2007; 21(1):76-80.

9. Polubothu S, Harrison S, Clement A, Kubba H. An audit of prophylactic antibiotic use in laryngeal reconstruction surgery. Int J Pediatr Otorhinolaryngol 2009;73(8):1157-9.

10. Hagiya H, Naito H, Hagioka S, Okahara S, Morimoto N, Kusano N, et al. Effects of antibiotics administration on the incidence of wound infection in percutaneous dilatational tracheostomy. Acta Med Okayama 2014;68(2):57-62.

11. Cardone G, Lepe M. Tracheostomy: complications in fresh postoperative and late postoperative settings. Clin Pediatr Emerg Med 2010; 11(2):122-30.

12. Lipový B, Brychta P, Rihová H, Suchanek I, Hanslianová M, Cvanová $\mathrm{M}$, et al. Effect of timing of tracheostomy on changes in bacterial colonisation of the lower respiratory tract in burned children. Burns 2013; 39(2):255-61.

13. Cline JM, Woods CR, Ervin SE, Rubin BK, Kirse DJ. Surveillance tracheal aspirate cultures do not reliably predict bacteria cultured at the time of an acute respiratory infection in children with tracheostomy tubes. Chest 2012;141(3):625-31.

14. McCaleb R, Warren RH, Willis D, Maples HD, Bai S, O'Brien CE. Description of respiratory microbiology of children with long-term tracheostomies. Respir Care 2016;61(4):447-52.

15. Sittitrai P, Siriwittayakorn C. Perioperative antibiotic prophylaxis in open tracheostomy: a preliminary randomized controlled trial. Int J Surg 2018;54(Pt A):170-5. 